\title{
SNHG5 wt Allele
}

National Cancer Institute

\section{Source}

National Cancer Institute. SNHG5 wt Allele. NCI Thesaurus. Code C132181.

Human SNHG5 wild-type allele is located in the vicinity of $6 q 14.3$ and is approximately 18 $\mathrm{kb}$ in length. This allele, which encodes long intergenic non-protein coding RNA 44, is involved in the synthesis of small nucleolar RNAs U50 and U50'. Translocation $\mathrm{t}(3 ; 6)$ (q27;q15) involving the SNHG5 and BCL6 genes is associated with B-cell lymphoma. 